\title{
Effect of hydrogen ions and inorganic complexing on the uptake of copper by the brine shrimp Artemia franciscana
}

\author{
Ronny Blust, Annemie Fontaine, Walter Decleir
}

Department of Biology, University of Antwerp, (RUCA), Groenenborgerlaan 171, B-2020 Antwerpen, Belgium

\begin{abstract}
The effect of hydrogen ions and inorganic complexing on copper uptake in the brine shrimp Artemia franciscana has been studied in chemically defined saltwater solutions. Uptake increases with decreasing hydrogen ion concentration and decreases with increasing carbonate complexation. A simple non-linear model that combines the effect of hydrogen ions on the transport of the metal across the solution-body interface and the effect of hydrogen ions and complexation on the speciation of the metal provided a close functional description of the observed variation in copper uptake by brine shrimp.
\end{abstract}

\section{INTRODUCTION}

The uptake and toxicity of copper in aquatic organisms is largely determined by the physical and chemical speciation of the metal in the environment and is related to the concentration of the free cupric ion in the solution (Borgmann 1983, Campbell \& Stokes 1985, Wangersky 1986, Luoma 1989). In a saltwater environment most of the copper is complexed by organic and inorganic ligands. Only a small fraction of the total amount of copper exists as the free cupric ion (Waite \& Morel 1983, Van den Berg 1984, Moffett \& Zika 1987. Sunda \& Hanson 1987, Turner \& Whitfield 1987, Coale \& Bruland 1988).

Experimental work carried out in saltwater solutions, where changes in the hydrogen ion concentration are minimal, have shown that complexation of copper with organic ligands decreases the uptake and toxicity of copper (Sunda \& Guillard 1976, Knezovich et al. 1981, Zamuda \& Sunda 1982, Ahsanullah \& Florence 1984, Zamuda et al. 1985, Blust et al. 1986, Florence \& Stauber 1986, Sunda et al. 1987). This effect is usually explained as resulting from decreases in the concentration of the cupric ion. Studies carried out in freshwater solutions, where changes in the hydrogen ion concentration are more pronounced, have also shown that complexation of copper with organic ligands decreases the uptake and toxicity of copper (Dodge \&
Theis 1979, Guy \& Kean 1980, Borgmann \& Ralph 1983, Buckley 1983, Starodub et al. 1987). However, it has also been shown that the uptake and toxicity of copper increases with decreasing hydrogen ion concentration and decreasing cupric ion concentration (Andrew et al. 1977, Howarth \& Sprague 1978, Chakoumakos et al. 1979, Miller \& Mackay 1980, Cusimano et al. 1986, Laurén \& McDonald 1986, Starodub et al. 1987). Under these circumstances the direct relation between the concentration of the cupric ion in solution and the uptake and toxicity of the metal in the aquatic organism is lost.

The first step in the uptake of copper from solution by an aquatic organism probably involves interaction with a membrane-embedded transport system to form a temporary association which carries the metal across the interface. Most such systems are sensitive to the binding of other positively charged species, most notably the hydrogen ion. Although the $\mathrm{pH}$ of saltwater remains relatively constant within space and time, the $\mathrm{pH}$ at the solution-body interface can vary considerably due to the activity of the specialised tissues which line the interface and create an intermediate environment differing from the external environment. Hydrogen ions may alter the availability of copper in 3 distinct ways: (1) changing the speciation of the metal in the solution; (2) modulating the activity of the metal transport system; and (3) affecting physiological processes 
which either directly or indirectly influence the uptake process (e.g. altering membrane potentials, ionic and osmotic regulation, energy metabolism) (Williams 1981, Simkiss \& Taylor 1989, Viarengo 1989).

To understand how these chemical and biological processes influence the availability of copper to organisms it is necessary to determine the combined effect of changes in the hydrogen ion concentration and in the inorganic speciation of copper on the uptake of the metal by multicellular organisms that live in saltwater environments. For this purpose we studied the combined effect of hydrogen ions and inorganic complexing on copper uptake in the brine shrimp Artemia franciscana.

\section{MATERIALS AND METHODS}

Brine shrimp. Dried Artemia franciscana cysts from Great Salt Lake, Utah, USA were purchased from San Francisco Bay Brand, Newark, CA, USA. Cysts were hatched in a funnel-shaped plastic container filled with synthetic seawater (Wiegandt, Krefeld, Germany), and aerated from the bottom. The hatching suspension was illuminated by a fluorescent light tube. Hatching cyst density was $5 \mathrm{~g} \mathrm{l}^{-1}$. Artemia nauplii were harvested after $36 \mathrm{~h}$. The larvae were grown from nauplii to adult in $150 \mathrm{l}$ plastic rectangular air-water lift operated raceways filled with synthetic seawater. Shrimp were fed with a suspension of Yellow-Mix (Artemia Systems, Ghent, Belgium). They reached maturity after 3 to $4 \mathrm{wk}$ and were used before they were $8 \mathrm{wk}$ old. The methods for intensive culturing of brine shrimp have been described by Sorgeloos et al. (1983).

Experimental procedures. In this study of the biological availability of copper to brine shrimp we used a static test design. The accumulation of copper during $3 h$ of exposure was used as a measure of the biological availability of the metal. Experiments were conducted in a thermostated room at $25.0 \pm 0.5^{\circ} \mathrm{C}$. One day before an experiment was run adult brine shrimp were collected from a batch culture and placed into clean medium to clear their guts. The composition of the chemically defined saltwater solution was (per liter) $23.50 \mathrm{~g} \mathrm{NaCl}, 4.00 \mathrm{~g} \mathrm{Na}_{2} \mathrm{SO}_{4}, 0.680 \mathrm{~g} \mathrm{KCl}, 0.196 \mathrm{~g}$ $\mathrm{NaHCO}_{3}, 1.470 \mathrm{~g} \mathrm{CaCl} 22 \mathrm{H}_{2} \mathrm{O}, 10.78 \mathrm{~g} \mathrm{MgCl} \cdot 6 \mathrm{H}_{2} \mathrm{O}$ and $0.026 \mathrm{~g} \mathrm{H}_{3} \mathrm{BO}_{3}$. The medium was prepared by dissolving the 7 analytical grade products (Merck p.a.) in deionised water. A dispersion of $0.1 \mathrm{mmol} \mathrm{I}^{-1} \mathrm{MnO}_{2}$ was added to the seawater to remove metals present in the analytical grade reagents. After an equilibration period of $24 \mathrm{~h}$, the dispersion was filtered through a $0.2 \mu \mathrm{m}$ membrane filter to remove the $\mathrm{MnO}_{2}$ from the solution (Van den Berg \& Kramer 1979). The $\mathrm{pH}$ of the solutions was controlled by incorporation of the zwitterionic buffers 2-( $\mathrm{N}$-morpholino)ethanesulphonic acid
(MES) and N-2-hydroxyethylpiperazine-N'-2-ethanesulphonic acid (HEPES) to control the pH between 5.3 and 6.8 and between 6.8 and 8.3 , respectively. These buffers form only weak complexes with divalent metal ions, and complexation of copper is negligible at the concentration of $10 \mathrm{mmol} l^{-1}$ MES or HEPES used (Good et al. 1966). The $\mathrm{pH}$ of the test solutions was adjusted with $\mathrm{HCl}$ or $\mathrm{NaOH}$ as required and the media were aerated to promote equilibration of gases with the atmosphere. At equilibrium the total dissolved $\mathrm{CO}_{2}$ concentration is determined by the $\mathrm{pH}$ of the solution and the partial pressure of $\mathrm{CO}_{2}$ in the atmosphere. To control the total dissolved $\mathrm{CO}_{2}$ concentration at fixed $\mathrm{pH}$ the solutions were aerated with synthetic air of known $\mathrm{CO}_{2}$ concentration (i.e. 0 to $5.0 \%$ ). Dissolved $\mathrm{O}_{2}$ concentration, total dissolved $\mathrm{CO}_{2}$ concentration, $\mathrm{pH}$ and redox potential $(\mathrm{pE})$ were measured to ensure that equilibrium conditions had established. Dissolved oxygen was measured with a polarographic oxygen electrode system (WTW OX191/EO90). Total dissolved $\mathrm{CO}_{2}$ was measured with a gas-sensing $\mathrm{CO}_{2}$ electrode (Ingold 152323000), after acidification of the water sample $(\mathrm{pH}<4.8)$ in a sealed measuring vessel. The hydrogen ion activity was measured with a glass electrode (Ingold 104573002), and $\mathrm{pH}$ values expressed on a free hydrogen ion scale (Millero 1986). Redox potentials were measured with a wire type platinum electrode (Ingold 105003077).

Copper was added to the test solutions from a 0.1 mmol $1^{-1}$ cupric ion stock [i.e. $\mathrm{Cu}\left(\mathrm{NO}_{3}\right)_{2}$ ]. In a first series of experiments the total concentration of copper in the test solutions ranged between 1 and 100 umol $1^{-1}$. Higher concentrations of copper could not be used due to the limited solubility of the metal. In a second series of experiments the total concentration of copper in the test solutions was $5 \mu \mathrm{mol} \mathrm{l}^{-1}$. Experiments were carried out in 0.51 plastic beakers. The test solutions were aerated during the experiments to maintain equilibrium. Just before an experiment started about 50 brine shrimp were collected on a $250 \mu \mathrm{m}$ screen, rinsed with clean medium and transferred to a beaker. After $180 \mathrm{~min}$ the beaker was removed and a few $\mathrm{ml}$ of the test solution sampled in a plastic vial and stored frozen at $-20^{\circ} \mathrm{C}$ until analysed for copper. The beaker was subsequently emptied over a $250 \mu \mathrm{m}$ screen. The collected shrimp were rinsed with deionised water and divided into 5 plastic vials, dried for $24 \mathrm{~h}$ at $60^{\circ} \mathrm{C}$ and stored in a dessication box until analysed for copper. All experiments were run at least in duplicate using brine shrimp from different batch cultures. For each treatment group 5 replicate samples were obtained. Dissolved $\mathrm{O}_{2}$ concentration, total dissolved $\mathrm{CO}_{2}$ concentration, $\mathrm{pH}, \mathrm{pE}$ and total dissolved copper concentration were measured at the beginning and end of an experiment. Generally, all measured values remained within $10 \%$ of initial values. 
Chemical modelling. The equilibrium concentrations of the chemical species considered were calculated using the computer program SOLUTION (Blust et al. unpubl.), an adaptation of the program COMPLEX (Ginzburg 1976). This speciation model allows calculation of the composition of solutions in equilibrium with gas and solid phases. The model uses the ion-association concept, which invokes the existence of molecular species like free ions, ion-pairs and complexes. A thermodynamic stability constant data base was built, based on the model of Dickson \& Whitfield (1981) for the major components and the models of Turner \& Whitfield (1987) and Sharma \& Millero (1988) for copper. For each ion-pair or complex species considered the stability constants listed for different ionic strengths were fitted to an interpolation function that has the form of an extended Debye-Hückel equation (Turner et al. 1981). The $\mathrm{pE}$ of the solutions was calculated from the empirical relation $\mathrm{pE}=17.6-\mathrm{pH}$ (Baas-Becking et al. 1960). The thermodynamic stability constants and concentration products at the ionic strength of the saltwater solution for all copper species included in the model are given in Table 1 . Case specific input includes the total concentrations of the metals and ligands in the solution, the free hydrogen ion concentration, redox potential, temperature and the gas and solid phases that are maintained in equilibrium with the solution.

Metal analysis. Copper was measured by Graphite Furnace Atomic Absorption Spectrophotometry using a Perkin-Elmer 703 Spectrophotometer fitted with a Heated Graphite Atomiser HGA-500 and a deuterium arc background corrector. The method of stabilised temperature platform atomisation was used (Slavin et al. 1983). Saltwater solutions were diluted 5 times with water. To this solution a one-tenth volume of concentrated nitric acid was added. The solutions were ana-

Table 1. Thermodynamic stability constants and concentration products for copper species. K: thermodynamic stability constant; Q: concentration product at $I=0.614$

\begin{tabular}{|lcc|}
\hline Species & Log $\mathrm{K}$ & Log Q \\
\hline $\mathrm{Cu}^{2+}$ & - & - \\
$\mathrm{CuCl}^{+}$ & 0.40 & -0.02 \\
$\mathrm{CuSO}_{4}{ }^{0}$ & 2.36 & 1.32 \\
$\mathrm{CuOH}^{+}$ & 6.01 & 5.61 \\
$\mathrm{Cu}^{+} \mathrm{OH}_{2}{ }^{0}$ & 11.75 & 10.83 \\
$\mathrm{CuCO}_{3}{ }^{0}$ & 6.74 & 5.73 \\
$\mathrm{CuHCO}_{3}{ }^{+}$ & 12.25 & 10.70 \\
$\left.\mathrm{Cu}^{2-} \mathrm{CO}_{3}\right)_{2}{ }^{2-}$ & 10.57 & 9.27 \\
$\mathrm{Cu}^{+}$ & 2.61 & 2.12 \\
$\mathrm{CuCl}^{0}$ & 5.72 & 4.85 \\
$\mathrm{CuCl}_{2}{ }^{-}$ & 8.03 & 7.21 \\
$\mathrm{CuCl}_{3}{ }^{2-}$ & 7.36 & 6.96 \\
\hline
\end{tabular}

lysed directly against matrix matched calibration standards. Biological material was dissolved with concentrated nitric acid in a microwave oven. The resulting digest was diluted with water and analysed against $10 \%$ nitric acid calibration standards (Blust et al. 1988).

Statistical analysis. All sets of data were tested for homoscedasticity by the log-ANOVA test for homogeneity of variances and for normality by the Kolmogorov-Smirnov test for goodness of fit. Analysis of variance, single and multiple linear regression and non-linear regression methods were used for analysing the data. The T-method was used to make multiple comparisons among pairs of means. Significance levels of tests are indicated as follows: $0.05 \geq p>0.01$, $\cdots 0.01 \geq p>0.001, \cdots p \leq 0.001$. Statistical methods are as outlined in Snedecor \& Cochran (1980) and Glantz \& Slinker (1990).

\section{RESULTS}

\section{Chemical speciation of copper}

The complexation of copper in a chemically defined saltwater solution that does not contain organic ligands is controlled by the concentration of hydroxide and carbonate. The concentration of hydroxide is determined by the $\mathrm{pH}$ of the solution. The concentration of carbonate is determined by the partial pressure of $\mathrm{CO}_{2}$ in the atmosphere and the $\mathrm{pH}$ of the solution. Changing the partial pressure of $\mathrm{CO}_{2}$ in the atmosphere makes it possible to alter the carbonate concentration without changing the $\mathrm{pH}$. Measurement of the $\mathrm{pH}$ and total dissolved $\mathrm{CO}_{2}$ concentrations in the solutions suffices for calculation of the carbonate speciation in a chemically defined solution. Results of measurements concerning the effects of $\mathrm{pH}$ and $\mathrm{CO}_{2}$ on the total dissolved $\mathrm{CO}_{2}$ concentration in the solutions and the effects on the chemical speciation of copper are summarised in Figs. 1 to 4 . In a basic environment copper is complexed with hydroxide and carbonate but towards acidic conditions the cupric ion and some covarying inorganic species (i.e. $\mathrm{CuCl}^{+}$and $\mathrm{CuSO}_{4}{ }^{\mathrm{O}}$ ), become increasingly more important. For the same total dissolved $\mathrm{CO}_{2}$ concentration, carbonate complexing is important in a basic, but not in an acidic environment.

\section{Uptake of copper by brine shrimp}

Results summarised in Fig. 5 show that the uptake of copper in brine shrimp increases linearly with the total concentration of the metal in the solution and 


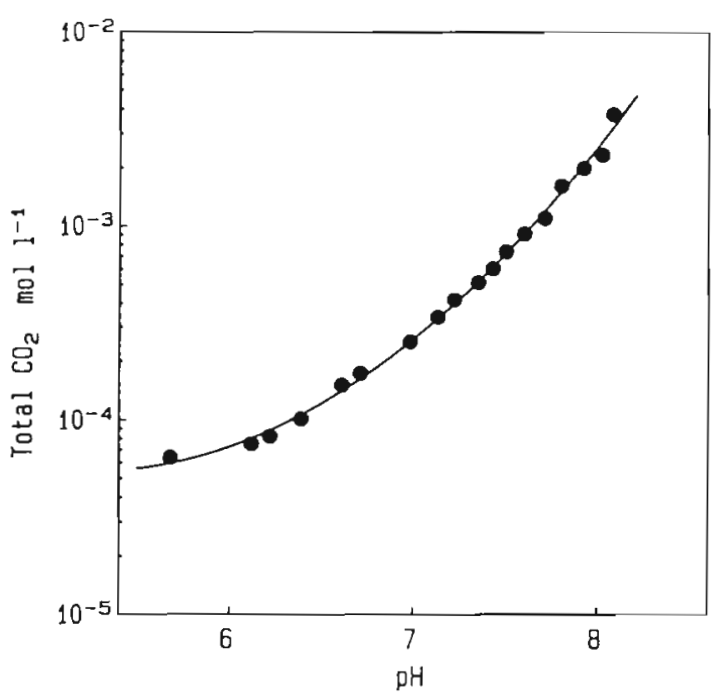

Fig. 1. Measured total dissolved carbon dioxide concentration as a function of $\mathrm{pH}$ in a saltwater solution in equilibrium with air (sal. $=3.5 \%, \mathrm{pO}_{2}=10^{-0.69}$ atm, $\mathrm{pCO}_{2}=10^{-3.48} \mathrm{~atm}$ )

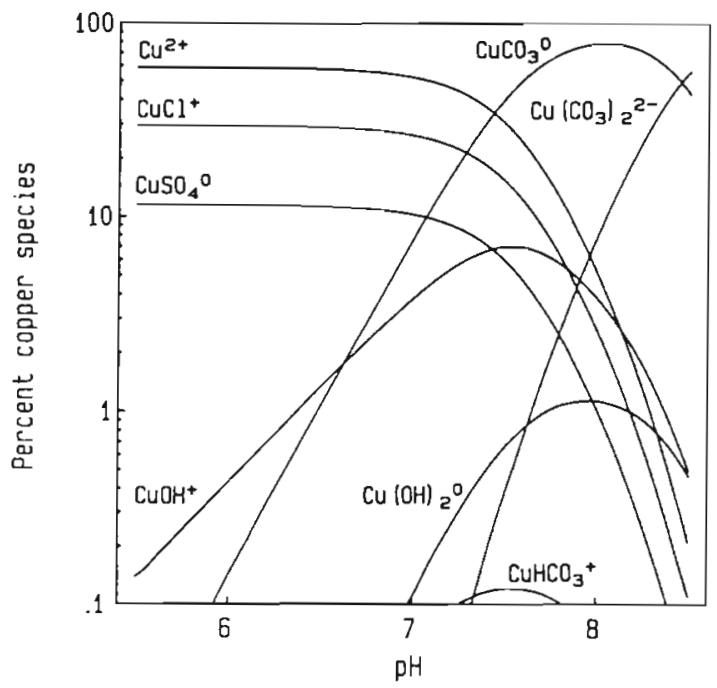

Fig. 2. Speciation model of copper as a function of $\mathrm{pH}$ in a saltwater solution in equilibrium with air (sal. $=3.5 \%, \mathrm{pO}_{2}=$ $\left.10^{-0.69} \mathrm{~atm}, \mathrm{pCO}_{2}=10^{-348} \mathrm{~atm}\right)$

that it is much higher in basic and neutral than in acid environments. Apparently, copper uptake does not saturate over the copper concentration ranges used $\left(\mathrm{pH}=6, \mathrm{Cu}_{\mathrm{T}}=10\right.$ to $100 \mu \mathrm{mol} \mathrm{l^{-1 }} ; \mathrm{pH}=7$ and 8, $\mathrm{Cu}_{\mathrm{T}}=1$ to $\left.10 \mu \mathrm{mol} \mathrm{l}^{-1}\right)$. Over the total copper and $\mathrm{pH}$ range tested, copper uptake is positively correlated with the concentrations of $\mathrm{Cu}^{2+}(\mathrm{r}=0.66 \cdots, \mathrm{n}=31)$, $\mathrm{CuOH}^{+}(\mathrm{r}=0.93 \cdots)$, and $\mathrm{CuHCO}_{3}{ }^{+}\left(\mathrm{r}=0.76^{\cdots} \cdots\right)$.

To determine the effect of complexation of copper with hydroxide and carbonate on the availability of copper at different $\mathrm{pH}$ values, subsequent experiments

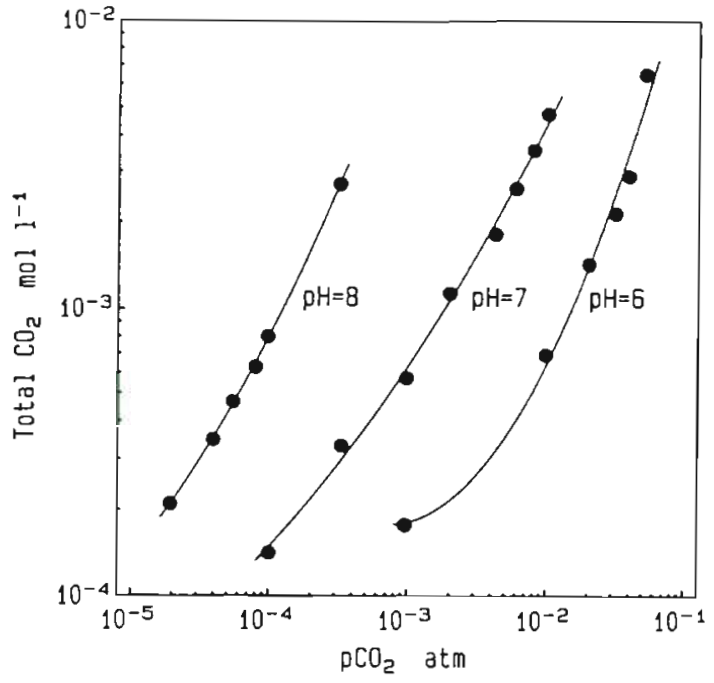

Fig. 3. Measured total dissolved carbon dioxide concentration as a function of $\mathrm{pH}$ and $\mathrm{pCO}_{2}$ in a saltwater solution (sal. = $\left.3.5 \%, \mathrm{pO}_{2}=10^{-069} \mathrm{~atm}\right)$

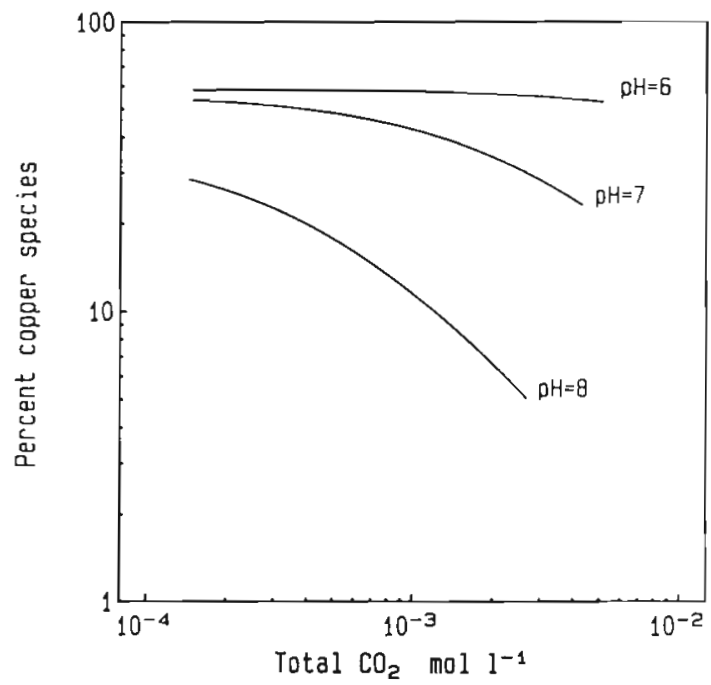

Fig. 4. Speciation model of copper as a function of $\mathrm{pH}$ and $\mathrm{pCO}_{2}$ in a saltwater solution (sal. $=3.5 \%, \mathrm{pO}_{2}=10^{-0.69} \mathrm{~atm}$ ). For clarity only the concentration of the cupric ion is shown

were conducted at one total copper concentration of 5 umol $1^{-1}, 3$ different $\mathrm{pH}$ values $(6.0,7.0$ and 8.0$)$, and different carbonate concentrations. The results summarised in Fig. 6 show that copper uptake increases with $\mathrm{pH}$. Over the $\mathrm{pH}$ range tested, copper uptake in brine shrimp is positively correlated with the concentrations of $\mathrm{CuOH}^{+}\left(r=0.79^{\circ}, \mathrm{n}=8\right), \quad \mathrm{Cu}(\mathrm{OH})_{2}{ }^{0}$ $\left(\mathrm{r}=0.88^{*}\right), \quad \mathrm{CuCO}_{3}{ }^{0}\left(\mathrm{r}=0.88^{*}\right)$ and $\mathrm{CuHCO}_{3}{ }^{+}$ $\left(\mathrm{r}=0.82^{\circ}\right)$. Results summarised in Fig 7 show that copper uptake decreases with the complexation of copper with carbonate. This effect is most pronounced at 

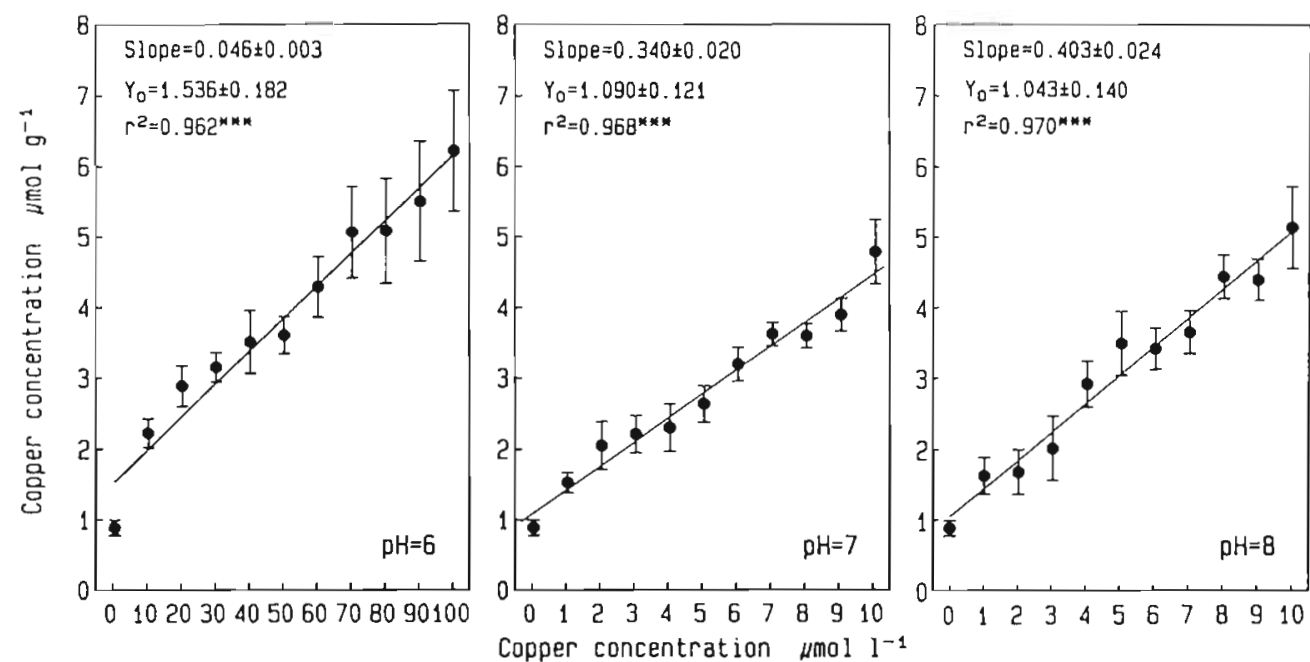

Fig. 5. Artemia franciscana. Uptake of copper at $\mathrm{pH}=6.0,7.0$ and 8.0 as a function of total copper concentration over a $3 \mathrm{~h}$ period (sal. $=3.5 \%, \mathrm{pO}_{2}=10^{-0.69} \mathrm{~atm}, \mathrm{pCO}_{2}=10^{-3.48} \mathrm{~atm}$ )

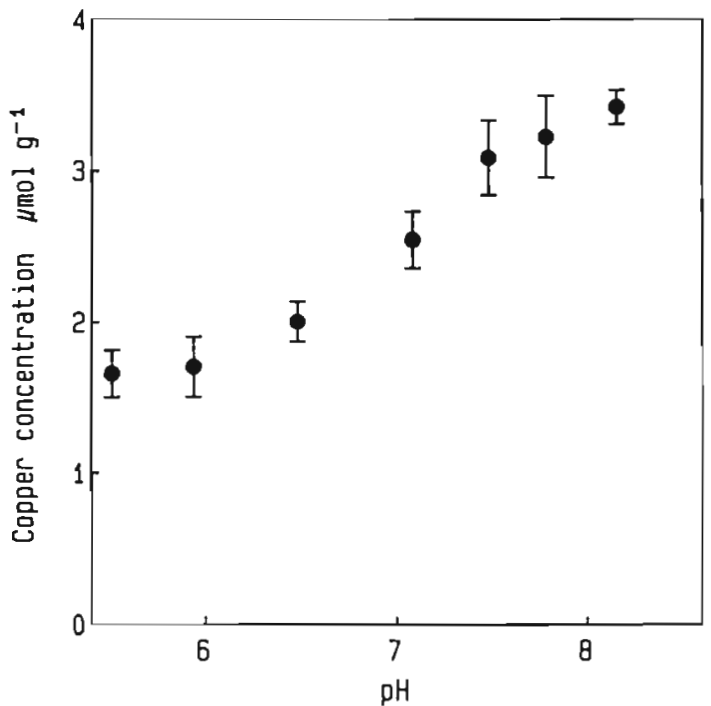

Fig. 6. Artemia franciscana. Uptake of copper as a function of $\mathrm{pH}$ over a $3 \mathrm{~h}$ period, exposed to a copper concentration of $5 \cdot 10^{-6} \mathrm{~mol} \mathrm{l}^{-1}\left(\mathrm{sal} .=3.5 \%, \mathrm{pO}_{2}=10^{-0.69} \mathrm{~atm}\right)$. Means are significantly different, $\mathrm{p}<0.01$

$\mathrm{pH} 8.0$ and 7.0. At pH 6.0 complexation of copper with carbonate is negligible, though a moderate decrease in copper uptake with increasing total carbon dioxide was observed. Over the $\mathrm{pH}$ range tested, copper uptake is positively correlated with the concentrations of $\mathrm{CuOH}^{+}\left(\mathrm{r}=0.98^{\cdots}, \mathrm{n}=21\right)$ and $\mathrm{Cu}(\mathrm{OH})_{2}{ }^{0}$ (r $=$ $0.98^{\cdots} \cdots$ ).

Analysis of the pooled results shows that overall, only the concentrations of the free cupric ion and the 2 cupric hydroxide species are positively correlated with the uptake of copper in brine shrimp. Results of the correlation analysis are summarised in Table 2.

\section{Linear and non-linear modelling of copper uptake}

Multiple linear regression analysis of the pooled results was used to explain the variation in copper uptake as the result of changes in the speciation of the metal on the uptake of a limited number of metal species. The linear equation for metal uptake assumes the form of a sum of terms. Each term is the product of a regression coefficient (RC) and the concentration of a metal species (MS). Taking into account the amount of copper already present in clean organisms $\left(\mathrm{M}_{0}\right)$, the equation for the total amount of copper in the organism $\left(\mathrm{M}_{\mathrm{T}}\right)$ becomes $\mathrm{M}_{\mathrm{T}}=\mathrm{M}_{0}+\mathrm{RC}_{1} \cdot \mathrm{MS}_{1}+\mathrm{RC}_{2} \quad \mathrm{MS}_{2}+\ldots$ Using this equation the analysis of the pooled results shows that most of the variation in copper uptake is explained when the free cupric ion and the 2 cupric hydroxide species are considered to be the metal species that are taken up. Results of the multiple linear regression analysis are summarised in Table $3 a$ and Fig. 8a. It has to be noted that the 2 copper hydroxide species considered show a high degree of collinearity which implies that their separate contribution cannot be assessed in an unambiguous way.

Multiple non-linear regression analysis of the pooled results was used to explain the variation in copper uptake as the combined effect of changes in the speciation of the metal and of changes in the hydrogen ion concentration on the uptake of a limited number of metal species. The effect of the hydrogen ions on metal uptake is expressed as an effect on the ionisation of the metal transport system. The non-linear equation for metal uptake assumes the form of an equilibrium relation between the concentrations of the hydrogen ion, the copper species taken up and the ionised carrier. The fraction of ionised carrier is determined by the acid 

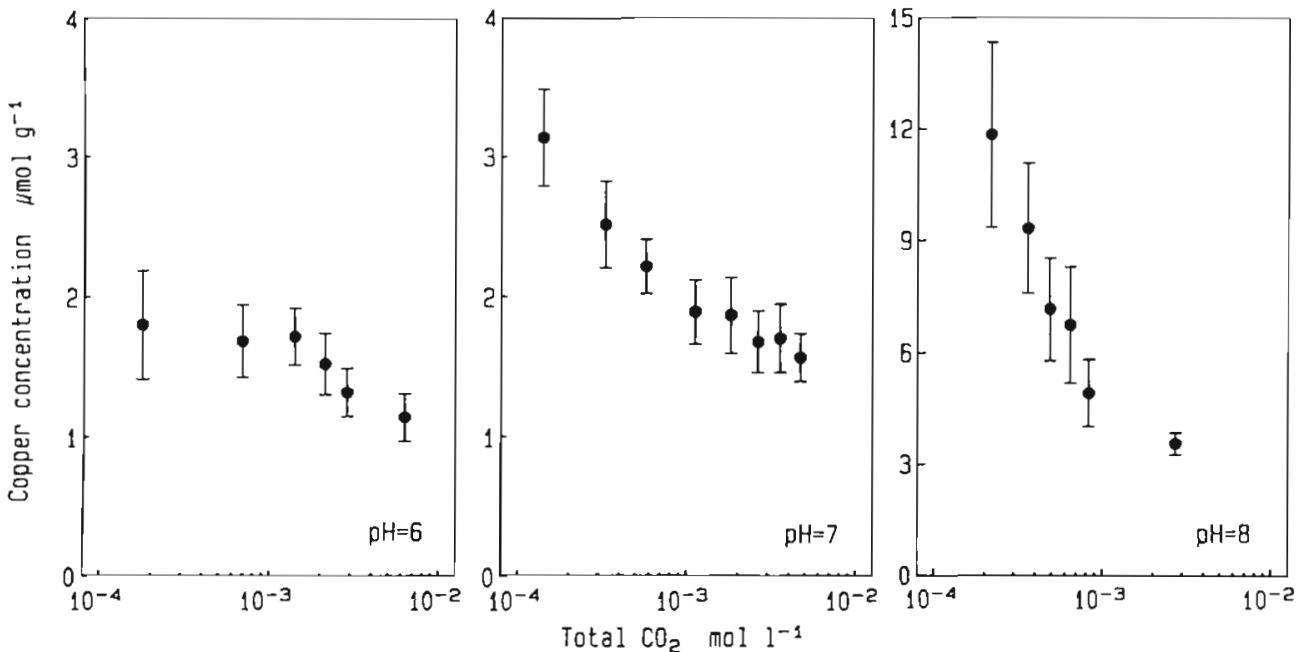

Fig. 7. Artemia franciscana. Uptake of copper at $\mathrm{pH}=6.0,7.0$ and 8.0 as a function of total dissolved carbon dioxide concentration over a $3 \mathrm{~h}$ period, exposed to a copper concentration of $5 \times 10^{-6} \mathrm{~mol} \mathrm{l} \mathrm{l}^{-1}$ (sal. $=3.5 \%, \mathrm{pO}_{2}=10^{-0.69}$ atm). Means are significantly different, $p<0.01$

Table 2. Copper speciation and uptake in brine shrimp: pooled data correlation matrix ( $\mathrm{n}=58$ ). ${ }^{\mathrm{ns}}$ Not significant; $\cdot 0.05 \geq p>0.01 ; \cdots 0.01 \geq p>0.001 ; \cdots p \leq 0.001$

\begin{tabular}{|c|c|c|c|c|c|c|}
\hline & $\mathrm{Cu}^{2++^{\mathrm{a}}}$ & $\mathrm{CuOH}^{+}$ & $\mathrm{Cu}(\mathrm{OH})_{2}{ }^{\circ}$ & $\mathrm{CuCO}_{3}{ }^{\circ}$ & $\mathrm{CuHCO}_{3}{ }^{+}$ & $\mathrm{Cu}\left(\mathrm{CO}_{3}\right)_{2}{ }^{2-}$ \\
\hline Uptake & $0.283^{\circ}$ & $0.958 \cdots$ & $0.810^{\cdots}$ & $0.257^{\mathrm{ns}}$ & $-0.061^{\mathrm{rs}}$ & $0.131^{\text {ns }}$ \\
\hline $\mathrm{Cu}^{2+*}$ & - & $0.171^{\text {ns }}$ & $-0.242^{\mathrm{ns}}$ & $-0.309^{\circ}$ & $0.549 \cdots$ & $-0.241^{\text {ns }}$ \\
\hline $\mathrm{CuOH}^{+}$ & - & - & $0.823 \cdots$ & $0.285^{\circ}$ & $-0.094^{n s}$ & $0.080^{\mathrm{ns}}$ \\
\hline $\mathrm{Cu}(\mathrm{OH})_{2}{ }^{0}$ & -- & - & - & $0.520^{\cdots}$ & $-0.279^{\circ}$ & $0.328^{\circ}$ \\
\hline $\mathrm{CuCO}_{3}{ }^{\mathrm{O}}$ & - & - & - & - & $-0.102^{\mathrm{ns}}$ & $0.886 \cdots$ \\
\hline $\mathrm{CuHCO}_{3}{ }^{+}$ & - & - & - & - & - & $-0.182^{\mathrm{ns}}$ \\
\hline \multicolumn{7}{|c|}{${ }^{d} \mathrm{Cu}^{2+}, \mathrm{CuCl}^{+}, \mathrm{CuSO}_{4}{ }^{0}$ vary together } \\
\hline
\end{tabular}

dissociation constant ( $\mathrm{pK}$ ) of the ligand and the $\mathrm{pH}$ of the solution [i.e. $1 /\left(1+10^{(\mathrm{pK}-\mathrm{pH})}\right)$ ]. Metal uptake is then proportional to the ratio of the fraction of available copper and the fraction of ionised carrier. To relate this ratio to metal uptake, it is necessary to introduce a coefficient (CF) which relates the sum of the concentrations of the metal species (SMS) in the solution to the concentration of copper taken up in the shrimps. Taking into account the amount of copper already present in clean organisms $\left(\mathrm{M}_{0}\right)$, the equation for the total amount of copper in the organism $\left(\mathrm{M}_{\mathrm{T}}\right)$ becomes $M_{\mathrm{T}}=\mathrm{M}_{0}+\mathrm{CF}$ SMS $1 /\left(1+10^{(\mathrm{pK}-\mathrm{pH})}\right)$. Using this equation analysis of the pooled results shows that most of the variation in copper uptake is explained when the acid dissociation constant of the transport system has a value of 8 and the cupric ion and the 2 cupric hydroxide species are considered to be the metal species that are taken up. Results of the multiple non-linear regression analysis are summarised in Table $3 b$ and Fig. $8 \mathrm{~b}$.
Table 3. Copper uptake in brine shrimp. (a) Pooled data linear regression ( $\mathrm{R}=0.979^{\cdots} \cdots, \mathrm{n}=58$ ); (b) pooled data non-linear regression $(R=0.961 \cdots, n=58)$. B: partial regression coefficient, $S E$ : standard error of partial regression coefficient; $L_{1}$, $\mathrm{L}_{2}: 95 \%$ confidence limits for partial regression coefficient; Intercept: copper concentration in clean shrimp $\left(\mathrm{M}_{0}\right)$. Concentrations are in $\mu \mathrm{mol} \mathrm{l}^{-1}$ for copper in solution and $\mu \mathrm{mol} \mathrm{g}^{-1}$ for copper in shrimp

\begin{tabular}{|lrrrr|}
\hline Variable & \multicolumn{1}{c}{$\mathrm{B}$} & $\mathrm{SE}$ & $\mathrm{L}_{1}$ & \multicolumn{1}{c}{$\mathrm{L}_{2}$} \\
\hline (a) Linear & & & & \\
Intercept & $1.276 \cdots$ & 0.091 & 1.094 & 1.458 \\
$\mathrm{Cu}^{2+}$ & $0.041 \cdots$ & 0.006 & 0.030 & 0.053 \\
$\mathrm{CuOH}^{+}$ & $6.032 \cdots$ & 0.678 & 4.673 & 7.391 \\
$\mathrm{Cu}(\mathrm{OH})_{2}{ }^{0}$ & $12.895 \cdots$ & 2.152 & 8.580 & 17.210 \\
(b) Non-linear & & & & \\
Intercept & $1.175 \cdots$ & 0.123 & 0.930 & 1.421 \\
Coefficient & $7.856 \cdots$ & 0.712 & 6.429 & 9.283 \\
pK & $8.036 \cdots$ & 0.063 & 7.911 & 8.161 \\
\hline
\end{tabular}


Fig. 8. Artemia franciscana. Predicted versus measured concentrations of copper for (a) the linear and (b) the non-linear mode
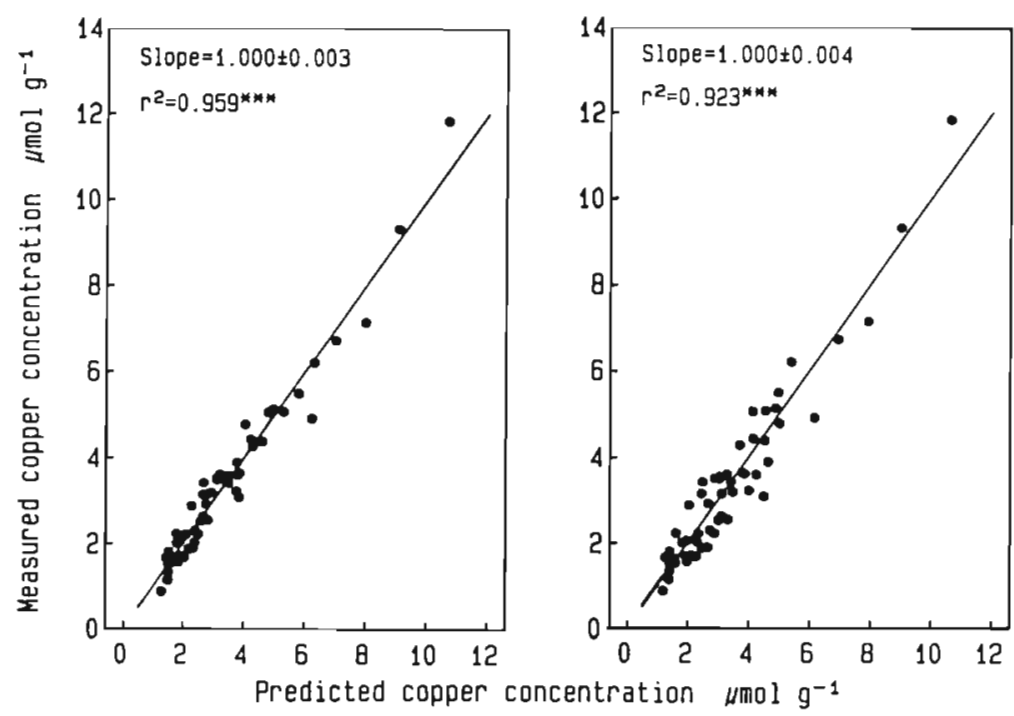

\section{DISCUSSION}

The results concerning the effect of different total copper concentrations on copper availability show that metal uptake is linear over the $\mathrm{pH}$ and concentration range used. This means that copper uptake is either (1) a simple diffusion process with the net rate of copper transport directly proportional to the concentration difference of the copper species across the solutionbody interface, or (2) a facilitated diffusion process, with the rate of transport limited by the number of transport sites and the maximum velocity at which they can function. In the latter case, uptake will appear linear until a critical concentration of copper is reached where the transport system becomes saturated. Within the range of total copper concentrations used, saturation of metal uptake in brine shrimp was not observed However, since the total concentration of copper which can be dissolved is constrained by the limited solubility of the cupric hydroxide and carbonate species, it cannot be concluded from these data whether or not the transport of copper across the solution-body interface is a simple or facilitated diffusion process.

The results concerning the effect of hydrogen ions and inorganic complexing show that the uptake of copper in brine shrimp is not simply related to the concentration of the cupric ion in the solution. Indeed, with increases of $\mathrm{pH}$ over the experimental range, the concentration of the cupric ion decreased sharply and yet a pronounced increase in the biological availability of copper was observed. This means that either (1) one or more of the inorganic complexes which prevail in basic conditions are available to the brine shrimp, and/ or (2) changes in the $\mathrm{pH}$ of the medium alter the metal uptake process, e.g. protonation of binding sites involved in the sequestration and transportation of copper occurs. That is, the biological availability of the free cupric ion and/or the other cupric ion species taken up increases with $\mathrm{pH}$. Since changes in the concentration of the cupric ion and the concentrations of the cupric hydroxide species are $\mathrm{pH}$ dependent, it is not experimentally possible, in an unambiguous way, to separate the effect of $\mathrm{pH}$ on the speciation of the metal from the effect of $\mathrm{pH}$ on the uptake process. Therefore, the observation that most of the variation in the availability of copper is explained by either a multiple linear or a non-linear regression model that includes the concentrations of the cupric ion and the cupric hydroxide species as independent variables, does not necessarily mean that there is also a true functional relationship between the concentration of all of these species and the availability of copper to the brine shrimp. It is, however, clear that changes in the hydrogen ion concentration have an important effect on the uptake of copper in the brine shrimp and that the observed variation in the uptake of copper is not explained by changes in the concentration of the free cupric ion alone.

The binding sites in a transport system are often weak acids, and the proportion of uncharged conjugate acid and charged conjugate base determines the number of sites available for metal binding. The proportion of conjugate base and conjugate acid is determined by the acid dissociation constant of the site. In this case, the amount of copper that is taken up is proportional to the product of the proportion of conjugate base of the site and the sum of the concentrations of the metal species taken up. Considering the cupric ion and the cupric hydroxide species as the most important biologically available species, non-linear regres- 
sion analysis of the data results in a calculated $p K$ value for the empirical binding site of 8.0.

Considering both the chemical and biological aspects of the metal uptake process, a conceptual model that relates metal speciation to metal availability can be built (Simkiss \& Taylor 1989, Viarengo 1989). Changes in the speciation of a metal can have important effects on the movement of the metal in the vicinity and across the solution-body interface. Ions and other polar species in solution are not bare because of interactions with the water molecules. The strength of these interactions with the water molecules increases with the charge density of the bare species, i.e. the ratio of the charge and the size of the species. The organisation of water molecules around the species results in the formation of a solvation sphere. This is a sphere of water molecules which are closely associated to the species and move around with it as one single moving entity. The bound water molecules contribute to the size of the species and it is the number of layers of solvent molecules which determines the effective size of the solvated species. The effective size of the solvated species in turn determines the mobility of the species in the solvent and hence its diffusion rate (Burgess 1988).

Basically, the solution-body interface has the structure of a negatively charged membrane which is bounded by an electrical double layer. The membrane is a fluid mosaic of proteins in a double layer of phospholipids. Some of these proteins function as carriers that bind solute molecules and carry them across the membrane. Other proteins build channels that perforate the membrane, creating diffusion paths whose resistance is less than that of the membrane itself. The electrical double layer is a sheet of solvated anions and cations with an excess of positive charges to balance the negative surface charge of the membrane. In the bulk phase, fluid convection carries the solute species to the proximity of the interface. The solute crosses the electrical double layer by passive diffusion. The flux of a non-electrolyte is determined by the concentration gradient or chemical potential of the solute across the interface. Charged species are subject to electrical forces and the driving force for electrolyte transport is determined by the electrochemical potential gradient rather than by the chemical potential alone (Blank 1987. Cevc 1990).

Since the solution-body interface is basically a hydrophobic structure, charged and neutral polar species cannot permeate the interface by dissolving in the phospholipid bilayer membrane and diffusing across to any extent. There is an enormous interfacial resistance to the transport of polar solutes through a highly apolar phase such as the hydrocarbon core of a biological membrane. It is therefore excluded that metal uptake is a simple diffusion process. This invokes the presence of transport systems that facilitate the translocation of the metal species across the interface (Eisenman \& Horn 1983, Wills \& Zweifach 1987). The strength of the interaction between a metal species and a carrier or channel binding site depends on the nature of the metal species and the binding site and is greater when the species can approach the site more closely. The results concerning the effect of inorganic complexing on the uptake of copper presented here, together with other studies concerning the effect of inorganic and organic complexing, have shown that the effect of complexation on the uptake and toxicity of copper in aquatic organisms does not depend on the stability constant or concentration product of the complexes formed (Sunda \& Guillard 1976, Andrew et al. 1977, Dodge \& Theis 1979, Guy \& Kean 1980, Knezovich et al. 1981, Zamuda \& Sunda 1982, Borgmann \& Ralph 1983, Buckley 1983, Ahsanullah \& Florence 1984, Zamuda et al. 1985, Blust et al. 1986, Florence \& Stauber 1986, Starodub et al. 1987). This indicates that the translocation of the metal across the solution-body interface only involves weak interactions. Hence, the effect of changes in the speciation of the metal on the uptake process appears the result of (1) changes in the concentration of the copper species for which the transport system is selective by charge and/or size, and (2) changes in the selectivity and/or activity of the transport system resulting from changes in the hydrogen ion concentration.

\section{CONCLUSIONS}

The results presented have shown that changes in the chemical speciation of copper on the uptake of copper in brine shrimp are not directly related to the concentration of the cupric ion alone when changes in the concentration of the hydrogen ion are considered. The observed variations in the uptake of copper are, however, reasonably well described by either a linear or non-linear model that considers the cupric ion and the cupric hydroxide complexes as the most important biologically available species. Since the transport of the metal species across the solution-body interface requires the presence of a facilitating system, the nonlinear model for copper uptake appears to be the more feasible integration of the effects of hydrogen ions and inorganic complexation on the availability of copper to the brine shrimp.

Acknowledgements. R.B. is a Senior Research Assistant of the National Fund for Scientific Research of Belgium. Hans van Hassel was responsible for maintenance of the brine shrimp culture facility. This work was sponsored by the Fund for Joint Basic Research of Belgium (project 2.0033.90) 


\section{LITERATURE CITED}

Ahsanullah, M., Florence, T M. (1984). Toxicity of copper to the marine amphipod Allorchestes compressa in the presence of water- and lipid-soluble ligands. Mar. Biol. 84 $41-45$

Andrew, R. W., Biesinger, K. E., Glass, G. E. (1977). Effects of inorganic complexation on the toxicity of copper to Daphnia magna. Wat. Res. 11-309-315

Baas-Becking, L. G., Kaplan, I. R., Moore, D. (1960). Limits of the natural environment in terms of $\mathrm{pH}$ and oxidationreduction potentials. J. Geol. 68: 243-284

Blank, M. (1987). The surface compartment model: a theory of ion transport focused on ionic processes in the electrical double layers at membrane protein interfaces. Biochim. Biophys. Acta 906: 277-294

Blust R., Van der Linden, A., Verheyen, E., Decleir, W. (1988). Evaluation of microwave heating digestion and graphite furnace atomic absorption spectrometry with continuum source background correction for the determination of $\mathrm{Fe}$, $\mathrm{Cu}$ and Cd in brine shrimp. J. Anal. At. Spectrom. 3: 387-393

Blust, R., Verheyen, E., Doumen, C., Decleir, W. (1986). Effect of complexation by organic ligands on the bioavailability of copper to the brine shrimp. Artemia. Aquat. Toxic. 8: 211-221

Borgmann, U. (1983). Metal speciation and toxicity of free metal ions to aquatic biota. In: Nriagu, J. O. (ed.) Advances in environmental science and technology, Vol. 13. John Wiley, New York, p. 47-72

Borgmann, U., Ralph, K. M. (1983). Complexation and toxicity of copper and the free metal bioassay technique. Wat. Res. 17: $1697-1703$

Buckley, J. A. (1983). Complexation of copper in the effluent of a sewage treatment plant and an estimate of its influence on toxicity to coho salmon. Wat. Res. 17: 1929-1934

Burgess, J. (1988). Ions in solution. Ellis Horwood, Chichester

Campbell, P. G. C., Stokes, P. M. (1985). Acidification and toxicity of metals to aquatic biota. Can. J. Fish. Aquat. Sci. 42: $2034-2049$

Cevc, G. (1990). Membrane electrostatics. Biochim. Biophys Acta 1031: 311-382

Chakoumakos, C., Russo, R. C., Thurston, R. V (1979). Toxicity of copper to cutthroat trout (Salmo clarki) under different conditions of alkalinity, $\mathrm{pH}$ and hardness. Environ. Sci Technol. 13: 213-218

Coale, K. H., Bruland, K. W. (1988). Copper complexation in the Northeast Pacific. Limnol. Oceanogr. 33: 1084-1101

Cusimano, R. F., Brakke, D. F., Chapman, G. A. (1986). Effects of $\mathrm{pH}$ on the toxicities of cadmium, copper and zinc to steelhead trout (Salmo gairdneri). Can. J. Fish. Aquat. Sci 43: $1497-1503$

Dickson, A. G., Whitfield, M. (1981). An ion-association model for estimating ácidity constants (at $25^{\circ} \mathrm{C}$ and 1 atm pressure) in electrolyte mixtures related to seawater (ionic strength $1 \mathrm{~mol} \mathrm{~kg}{ }^{-1}$ ). Mar. Chem. 10: 315-333

Dodge, E. E., Theis, T. L. (1979). Effect of chemical speciation on the uptake of copper by Chironomus tentans. Environ. Sci. Technol. 13: 1287-1288

Eisenman, G., Horn, R. (1983). Ionic selectivity revisited: the role of kinetic and equilibrium processes in ion permeation through channels. J. Membrane Biol. 76: 197-225

Florence, T. M., Stauber, J. L. (1986). Toxicity of copper complexes to the marine diatom Nitzschia closterium. Aquat. Tox. 8: 11-26

Glantz, S. A., Slinker, B. K. (1990). Primer of applied regres sion and analysis of variance. McGraw-Hill, New York

Good, N. E., Winget, G. D., Winter, W., Connoly, T N. (1966).
Hydrogen ion buffers for biological research. Biochemistry 5: $467-477$

Ginzburg, G. (1976). Calculation of all equilibrium concentrations in a system of competing complexation. Talanta 23: $142-149$

Guy, R. D., Kean, A. R. (1980). Algae as a chemical speciation monitor I. A comparison of algal growth and computer calculated speciation. Wat. Res. 14: 891-899

Howarth, R. S., Sprague, J. B. (1978). Copper lethality to rainbow trout in waters of various hardness and $\mathrm{pH}$. Wat. Res. 12: 455-462

Knezovich, J. P., Harrison, F. L., Tucker, J. S. (1981). The influence of organic chelators on the toxicity of copper to embryos of the Pacific oyster, Crassostrea gigas. Arch. environ. Contam. Toxicol. 10: 241-249

Laurén, D. J., McDonald, D. G. (1986). Interactions of water hardness, $\mathrm{pH}$ and alkalinity with the mechanisms of copper toxicity in juvenile rainbow trout, Salmo gairdneri Can. J. Fish. Aquat. Sci. 43: 1488-1496

Luoma, S. N. (1989). Can we determine the biological availability of sediment-bound trace elements? Hydrobiologia 176/177: 379-396

Miller, T G., Mackay, W. C. (1980). The effects of hardness, alkalinity, and $\mathrm{pH}$ of test water on the toxicity of copper to rainbow trout Salmo gairdneri. Wat. Res. 14: 129-133

Millero, F. J. (1986). The $\mathrm{pH}$ of estuarine waters. Limnol Oceanogr 31: 839-847

Moffett, J. W., Zika, R. G. (1987). Solvent extraction of copper acetylacetonate in studies of copper(II) speciation in seawater Mar Chem. 21, 301-313

Sharma, V K., Millero, F. J. (1988). The oxidation of Cu(I) in electrolyte solutions. J. Solution Chem. 17. 581-599

Simkiss, K., Taylor, M. G. (1989). Metal fluxes across the membranes of aquatic organisms. CRC Crit. Rev. Aquat. Sci. 1. 173-188

Slavin, W., Carnrick, G. R., Manning, D. C. (1983). Recent experiences with the stabilized platform furnace and zeeman background correction. At. Spectrosc. 4: 69-86

Snedecor, G. W., Cochran, W G. (1980). Statistical methods Iowa State University Press, Ames

Sorgeloos, P., Bossuyt, E., Lavens, P., Léger, P., Vanhaecke, P. Versichele, D. (1983). The use of brine shrimp Artemia in crustacean hatcheries and nurseries. In: McVey, J. P. (ed.) Handbook of mariculture, Vol. 1. CRC Press, Boca Raton p. 71-96

Starodub, M. E., Wong, P. T S., Mayfield, C. I., Chau, Y. K (1987). Influence of complexation and $\mathrm{pH}$ on individual and combined heavy metal toxicity to a freshwater alga Can. J. Fish. Aquat. Sci. 44: 1173-1180

Sunda, W G., Guillard, R. R. L. (1976). The relationship between cupric ion activity and the toxicity of copper to phytoplankton. J. mar. Res. 34: 511-529

Sunda, W G., Hanson, A. K. (1987). Measurement of free cupric ion concentration in seawater by a ligand competition technique involving copper sorption onto $\mathrm{C}_{18}$ SEPPAK cartridges. Limnol. Oceanogr. 32: 537-551

Sunda, W. G., Tester, P. A., Huntsman, S. A. (1987). Effects of cupric and zinc ion activities on the survival and reproduction of marine copepods. Mar. Biol. 94: 203-210

Turner, D. R., Whitfield, M. (1987). An equilibrium speciation model for copper in sea and estuarine waters at $25^{\circ} \mathrm{C}$ including complexation with glycine EDTA and NTA Geochim. Cosmochim. Acta 51: 3231-3239

Turner, D. R., Whitfield, M., Dickson, A. G. (1981). The equilibrium speciation of dissolved components in freshwater and seawater at $25^{\circ} \mathrm{C}$ and $1 \mathrm{~atm}$ pressure. Geochim. Cosmochim. Acta 45: 855-881 
Van den Berg, C. M. G. (1984). Determination of the complexation capacity and conditional stability constants of complexes of copper(II) with natural organic ligands in seawater by cathodic stripping voltammetry of coppercatechol complex ions. Mar. Chem. 15: 1-18

Van den Berg, C. M. G., Kramer, J. R. (1979). Determination of complexing capacities of ligands in natural waters and conditional stability constants of the copper complexes by means of manganese dioxide. Analyt. Chim. Acta 106: $113-120$

Waite, T. D., Morel, F. M. M. (1983). Characterization of complexing agents in natural waters by copper(II)/copper(I) amperometry. Analyt. Chem. 55: 1268-1274

Wangersky, P. J. (1986). Biological control of trace metal residence time and speciation: a review and systhesis. Mar. Chem. 18: 269-297

This article was submitted to the editor
Viarengo, A. (1989). Heavy metals in marine invertebrates: mechanisms of regulation and toxicity at the cellular level. CRC Crit. Rev. Aquat. Sci. 1: 295-317

Williams, R. J. P. (1981). Physico-chemical aspects of inorganic element transfer through membranes. Phil. Trans. R. Soc. Lond. B294: 57-74

Wills, N. K. Zweifach, A. (1987). Recent advances in the characterization of epithelial ionic channels. Biochim. Biophys. Acta 906: 1-31

Zamuda, C. D., Sunda, W. G. (1982). Bioavailability of dissolved copper to the American oyster Crassostrea virqinica. I. Importance of chemical speciation. Mar Biol. 66: 77-82

Zamuda, C. D., Wright, D. A., Smucker, R. A. (1985). The importance of dissolved organic compounds in the accumulation of copper by the American oyster, Crassostrea virginica. Mar environ. Res. 16: 1-12

Manuscript first received: March 28, 1991

Revised version accepted: August 16, 1991 